\title{
The Hindwings of Ants: A Phylogenetic Analysis
}

\author{
Stefano Cantone $(\mathbb{D}$ and Claudio José Von Zuben \\ Department of Zoology, São Paulo State University, Rio Claro, SP, Brazil \\ Correspondence should be addressed to Stefano Cantone; cantonestefano@gmail.com
}

Received 11 February 2019; Accepted 27 March 2019; Published 14 April 2019

Academic Editor: Jan Klimaszewski

Copyright (c) 2019 Stefano Cantone and Claudio José Von Zuben. This is an open access article distributed under the Creative Commons Attribution License, which permits unrestricted use, distribution, and reproduction in any medium, provided the original work is properly cited.

\begin{abstract}
In this study, we compare and analyze different ant taxa hindwing morphologies with phylogenetic hypotheses of the Family Formicidae (Hymenoptera). The hindwings are classified into three Typologies based on progressive veins reduction. This analysis follows a revision of the hindwing morphology in 291 extant and eight fossil genera. The distribution of different Typologies was analyzed in the two Clades: Formicoid and Poneroid. The results show a different distribution of Typologies, with a higher genera percentage of hindwings of Typology I in the Clade Poneroid. A further analysis, based on genetic affinities, was performed by dividing the Clades into Subclades, showing a constant presence of hindwings of Typology I in almost all the Subclades, albeit with a different percentage. The presence of hindwings of Typology I (hypothesized as more ancestral) in the Subclades, indicates the genera that could be morphologically more similar to their ancestral ones. This study represents the first revision of the ants' hindwings, showing an overview of the distribution of different Typologies.
\end{abstract}

\section{Introduction}

The wings in ants are present only in the winged reproductive caste and have the important function of promoting the meeting between two sexes for mating. Wings are used exclusively for the nuptial flight and after mating winged Queens lose these structures and the winged male dies. The knowledge about the distance traveled in this flight is unknown, but the loss of wings in the queens suggests a short distance of dispersion $[1,2]$.

Wing dimensions are directly proportional to body size, but vein structure has no relation to body size. In fact, wings with "complete" vein morphology are described in small body species and wings with reduced vein morphology in large ants [3-5]. Thus, the evolutionary pathway of the wing vein structure is independent of body size, representing an important character in phylogenetic studies. In addition, in some genera described vein structure varies between species and in some species in the forewing between males and queens, showing a venational evolution in progress $[3,4,6-$ 8]. The stability of wing vein structure is also confirmed by the constancy and permanence for millions of years as described in fossils from the Cretaceous and Eocene ants. In particular, in the Eocene epoch, most of the extinct species described have been classified in extant genera or subfamilies, and wing morphology is similar or equal, representing an important characteristic in the identification of fossil winged forms and widely used by various scientists.

In comparative studies on ant wings, more attention was given to the forewings, assuming an evolutionary history based on wing morphology $[3-7,9,10]$. The different morphology of the wing veins is an important characteristic in the evolutionary history of the genera within the Subfamilies, Tribe, or Group-genera identified by phylogenetic hypotheses based on molecular genetic analysis and sophisticated statistical analysis.

The first brief and incomplete analysis of the hindwings of ants was made by Kusnezov [11], who shows the different morphologies present in some genera. Recently, a broader review was made by Cantone $[3,4]$, which classifies ant hindwings into three Typologies based on progressive wing vein reduction. The objective of this study is to analyze and compare the hindwing vein structure with phylogenetic hypotheses, in the most ant genera, in order to present a distribution overview of the different hindwing morphologies in the family Formicidae. 
Hindwing of Typology I

Hindwing of Typology I with Jugal lobe
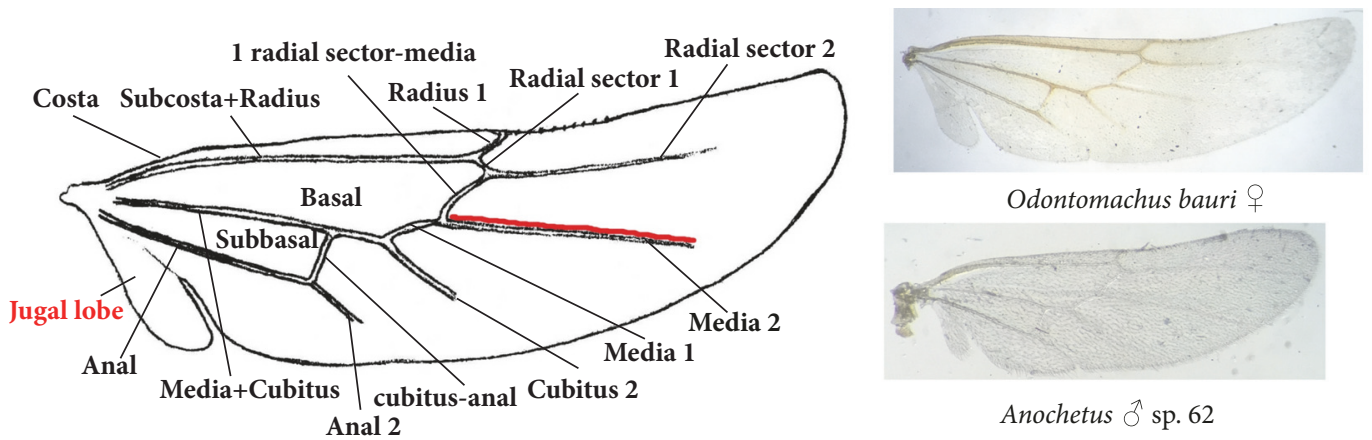

Odontomachus bauri ㅇ

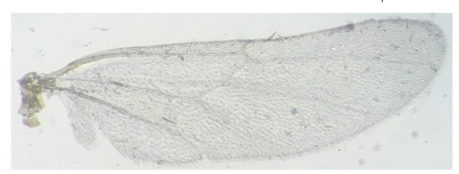

Anochetus ð sp. 62

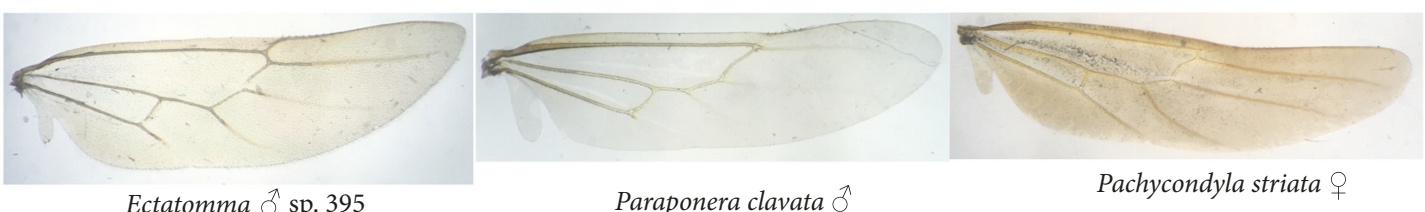

Hindwing of Typology I without Jugal lobe

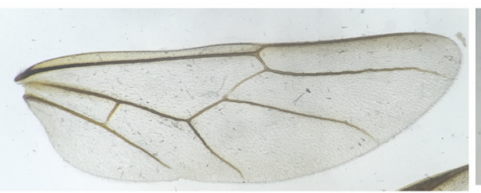

Neivamyrmex sp. R1

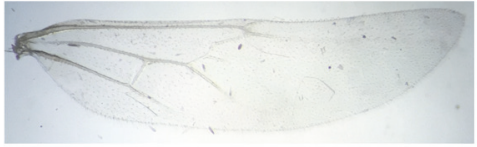

Acanthoponera § sp. 405

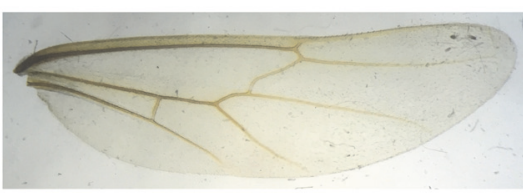

Labidus coecus §ै

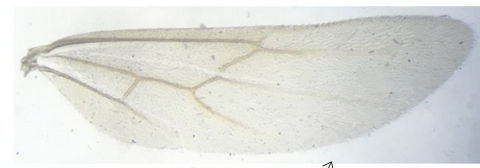

Leptogenys $\widehat{\jmath} \mathrm{sp}$

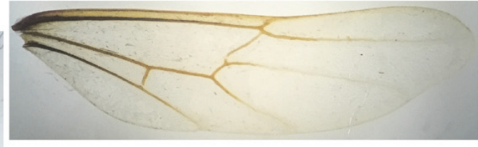

Eciton quadriglume

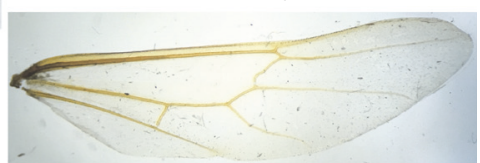

Nomamyrmex esenbeckii

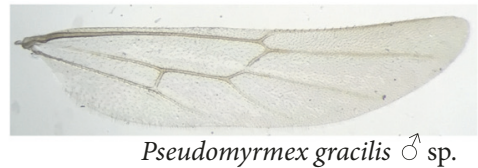

Hindwing of Typology I without Jugal lobe "azteca type"

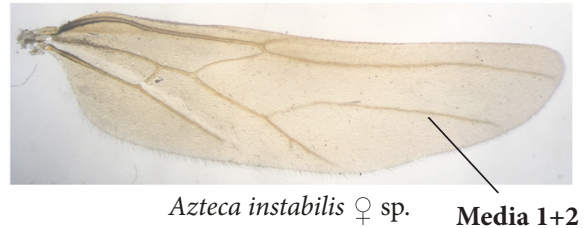

Figure 1: Hindwing of Typology I with Cells and Veins terminology. The photos represent some examples of hindwings of Typology I; the dimensions are not comparable (photos by personal Cantone collection of Winged Ants).

\section{Materials and Methods}

Hindwings morphology was analyzed in 299 genera, of which 291 were extant and eight fossils. This analysis is based on the study and revision of extant genera of winged males in 260 genera [3] and winged Queens in 244 genera [4]. Hindwings were classified into three Typologies, based on progressive wing vein reduction. The terminology of hindwings venation follows Yoshimura and Fisher [12] and Serna et al. [13].

Fossil specimen hindwings were examined from deposits or ambers in Cretaceous and Eocene epochs and have been based on genera belonging to the extinct Subfamilies Sphecomyrminae, Formiciinae, and on some extinct genera currently included in Incertae sedis. 


\section{Hindwing of Typology II}

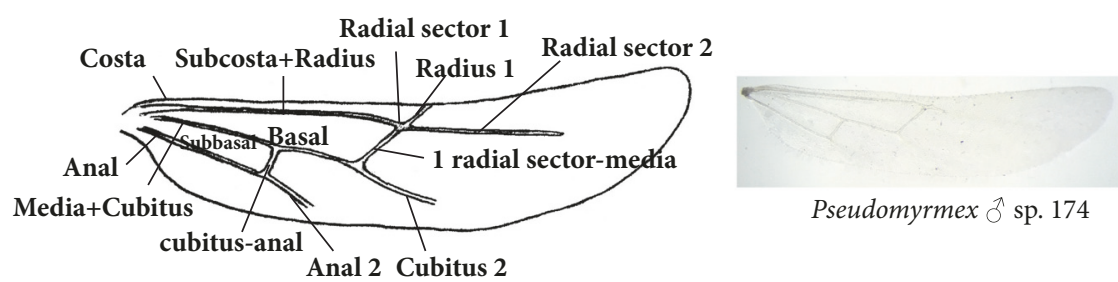

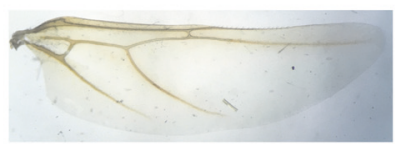

Camponotus $q$ sp. 42

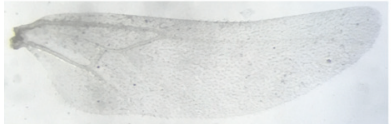

Dolichoderus lamellosus

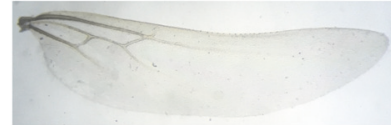

Dorymyrmex pyramycus 우

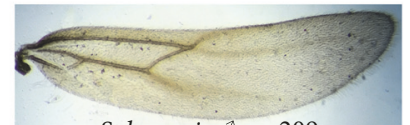

Solenopsis ô sp. 209

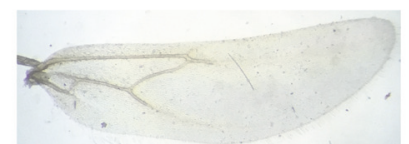

Pheidole ôs sp. 199

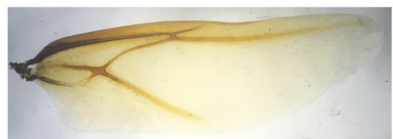

Atta sexdens ठै

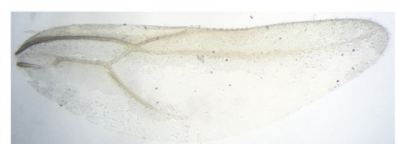

Nylanderia + sp. 8

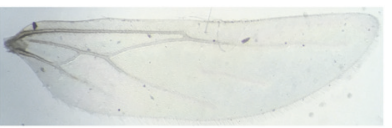

Linepithema fuscum $\precsim$

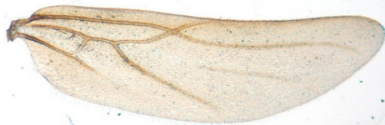

Anillidris bruchi
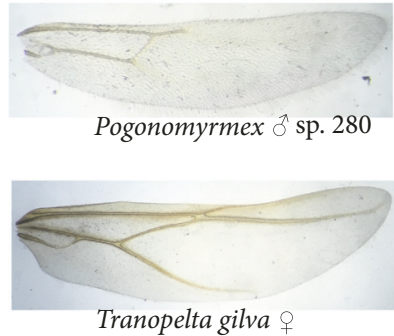

Tranopelta gilva

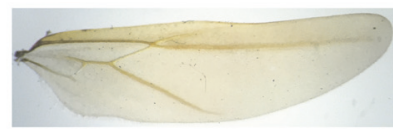

Acromyrmex §े sp.

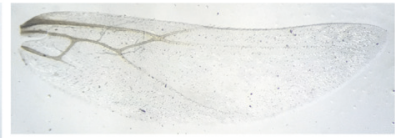

Formica exsecta 우

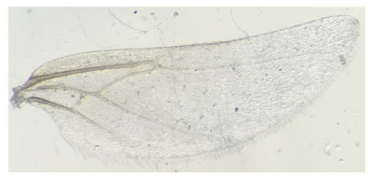

Linepithema humile $\delta$

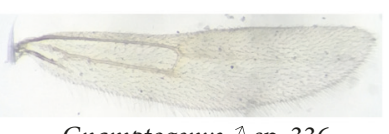

Gnamptogenys ð̊ sp. 336
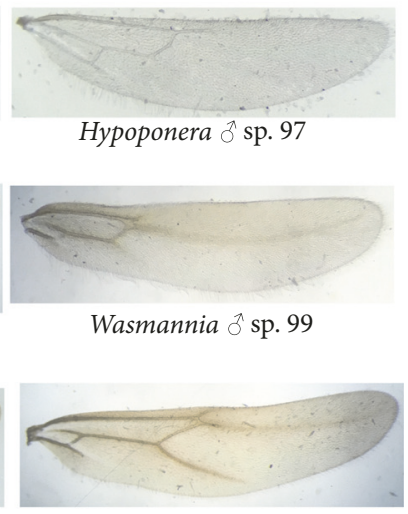

Procryptocerus ô sp. 382

Figure 2: Hindwing of Typology II with Cells and Veins terminology. The photos represent some examples of hindwings of Typology II; the dimensions are not comparable (photos by personal Cantone collection of Winged Ants).

The study and description of hindwing morphology were based on the study of photos available on the AntWeb website and personal Cantone collection of Winged Ants, as well as being based on the review of scientific articles related to species descriptions. A Leica MZ8 stereoscope was utilized and hindwings photos were taken in order to show some examples of different Typologies.

The phylogenetic analysis is based on the comparison between hindwing Typologies and phylogenetic hypotheses are based on molecular genetic analysis that divides the family Formicidae into two Clade and into groups of genera [14-16].

\section{Results}

\subsection{Hindwings Typologies Classification}

3.1.1. Hindwings of Typology I (Figure 1). In this Typology, hindwings have a more complete venation within the Family Formicidae. Basal and subbasal cells and media 2 vein are always present. They differ in the presence/absence of the jugal lobe. Alternative morphology with media $1+2$ vein, that is, for the first time, described and denominated as "azteca type". The hindwings of Typology I are present in some genera of Subfamilies Amblyoponinae, Dolichoderinae, Dorylinae, Ectatomminae, Heteroponerinae, Myrmeciinae, 
Hindwing of Typology III
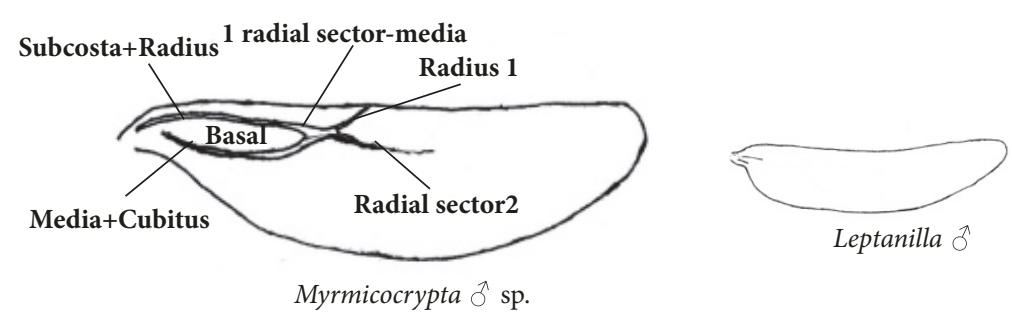

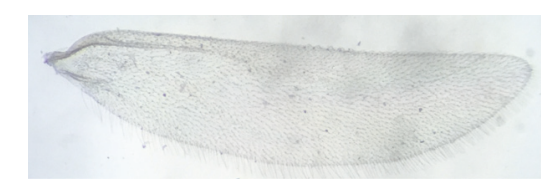

Crematogaster ふैsp. 6

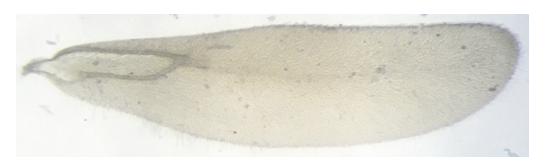

Cyphomyrmex ठै sp. 3

FIgURE 3: Hindwing of Typology III with Cells and Veins terminology. The photos represent some examples of hindwings of Typology III; the dimensions are not comparable (photos by personal Cantone collection of Winged Ants).

Ponerinae, and Paraponerinae. In the Subfamilies Myrmicinae and Pseudomyrmicinae only some species present hindwings of Typology I: Solenopsis bicolor Emery, described with hindwings of Typology I "azteca type" [11, 17], representing a rare and unique case in the subfamily Myrmicinae; Pseudomyrmex gracilis, described with hindwings of Typology I without jugal lobe by Kusnezov [11], and some species of the genus Tetraponera representing rare case in the subfamily Pseudomyrmecinae (see Figure 1).

The jugal lobe is present in some genera of the Subfamilies Ponerinae, Ectatomminae, Myrmeciinae, and Paraponerinae. The hindwings of Typology I with jugal lobe are described in 38 genera, and the hindwings of Typology I without jugal lobe are described in 43 genera belonging to 10 Subfamilies (see Table 1). In seven genera of the Subfamily Ponerinae the hindwings are not described; therefore, assuming to be of Typology I, they will be analyzed in both genera with or without jugal lobe (see notes in Table 1), $[3,4]$.

3.1.2. Hindwings of Typology II (Figure 2). In this Typology II, the hindwings differ from Typology I due to the absence of the media 2 vein and the absence of jugal lobe. They are present in the genera of Subfamilies Amblyoponinae, Aneuretinae, Agroecomyrmecinae, Dolichoderinae, Dorylinae, Ectatomminae, Heteroponerinae, Formicinae, Myrmicinae, Ponerinae, Proceratiinae, and Pseudomyrmecinae. The hindwings of Typology II are described in 177 genera $[3,4]$.

3.1.3. Hindwings of Typology III (Figure 3). In this Typology, there is a drastic reduction of veins with a reduced or absent anal vein and the subbasal cell absent. The subfamily Leptanillinae exhibits an extreme case of structural reduction, with the basal and subbasal cells absent. The hindwings of Typology III are present in the genera of Subfamilies
Amblyoponinae, Apomyrminae, Dolichoderinae, Dorylinae, Leptanillinae, Martialinae, Myrmicinae, and Proceratiinae. The hindwings of Typology III are described in 41 genera $[3,4]$.

3.2. Hindwings of Extinct Ants in the Cretaceous and Eocene. The oldest fossil ants were found in ambers or sediments of the Late Cretaceous, between 110 and 75 million years ago (Ma) in North America (Canadian amber ca. 78-79 Ma; New Jersey amber, ca. 94-90 Ma); in Botswana (Orapa, Tutorian deposit ca. $90 \mathrm{Ma}$ ); in Russia (Siberia ca. $85 \mathrm{Ma}$ ); in France (Charentes, ca. $100 \mathrm{Ma}$ ); and in Myanmar (Burmese amber, ca. $99 \mathrm{Ma}$ ). The species in which the hindwings are described were classified in the extinct Subfamily Sphecomyrminae or in some genera classified as Incertae Sedis in the Cretaceous. Hindwings are known from 10 species, of seven genera of Cretaceous ants. In nine species the hindwings are of Typology I and the anal area is not visible, not showing the presence/absence of the jugal lobe; the only case described by Perfilieva $[5,18]$ is Armania robusta hindwing with jugal lobe. Only a male belonging to the genus Camelomecia has the hindwings of Typology II, but the identification is uncertain [19]. Figure 4 shows the wings of the fossil species of the Cretaceous divided by geographical region; the drawings of the wings described have been modified in the dimensions by the original descriptions.

In the Eocene, the greatest numbers of ant fossils were found, all of them classified as belonging to current Subfamilies and, in many species, to extant genera. In these cases, all the species described through the winged caste have wings comparable by morphology to extant genera. A single case is the extinct genus Titanomyrma (Formicium) belonging to the Subfamily Formiciinae with fossils dating back to the early-middle Eocene (48-41 Ma). The hindwings of the genus Titanomyrma can be classified in Typology I without jugal lobe. These fossil species have been encountered 
Hindwings of Cretaceous Ants
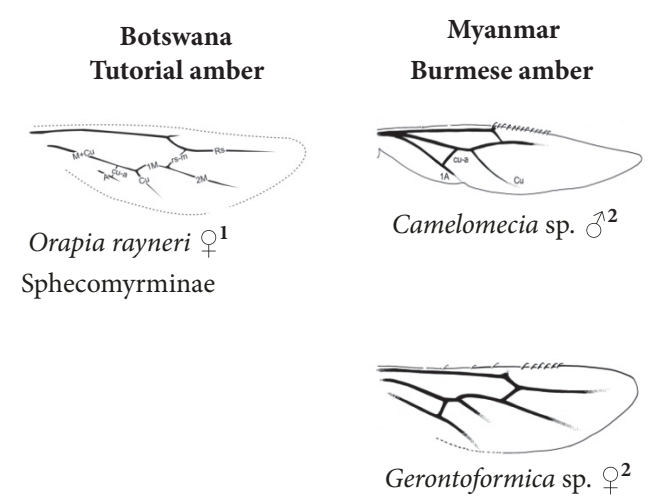

1: drawing modified by Dlussky et al., 2004

2: drawing modified by Barden and Grimaldi, 2016

3: drawing modified by Grimaldi et al., 1997

4: drawing modified by Perfilieva, 2002, 2010
New Jersey, USA

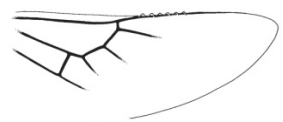

Sphecomyrminae $\delta^{33}$

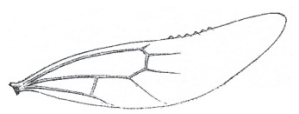

Sphecomyrma? $\delta^{3}$ Sphecomyrminae

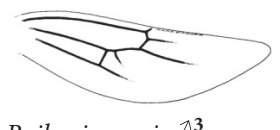

Baikuris casei j $^{33}$ Sphecomyrminae

Figure 4: Summary hindwings of Cretaceous Ants (110-75 Ma).

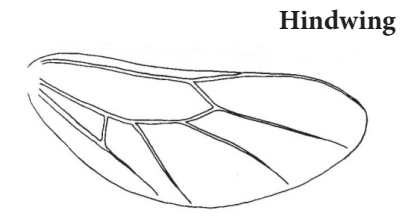

Titanomyrma (Formicium) gigantea $^{1}$
Russia Taymyr amber
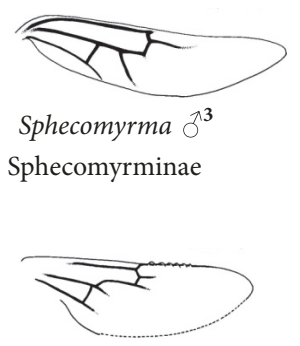

Dlusskyidris zherikini $\AA^{3}$

Sphecomyrminae

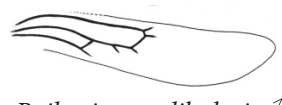

Baikuris mandibularis j $^{13}$ Sphecomyrminae

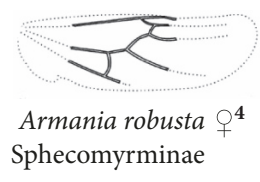

1: drawing modified by Lutz, 1986.

FIGURE 5: Hindwing of genus Titanomyrma.

in Germany (Eckfeld/Messel shale) and in USA (Green River Formation) [20, 21]. Figure 5 shows the hindwings of genus Titanomyrma (Formicium), as described by Lutz [21], with modified drawings in the dimensions.

3.3. Phylogenetic Analysis of the Ants' Hindwings. According to the phylogenetic hypothesis, based on molecular genetic analysis, made by Brady et al. [14], Morreau et al. [15], and Morreau and Bell [16], the Family Formicidae is divided into two Clades: Poneroid and Formicoid. The Subfamilies Leptanillinae and Martialinae present an independent evolutionary path.
The Clade Poneroid is divided into three phylogenetically distinct groups: the first group includes the genera of the Subfamilies Ponerinae, Paraponerinae, and Agroecomyrmecinae that in this analysis we called Subclade Poneroid 1; the second group includes the genera of the Subfamily Amblyoponinae that we called Subclade Poneroid 2; the third group includes the genera of the Subfamily Proceratiinae that we called Subclade Poneroid 3. Thus, in this analysis the Poneroid Clade is divided into three phylogenetically distinct Subclades.

The Clade Formicoid, in the hypothesis of Brady et al. [14], Morreau et al. [15], Morreau and Bell [16], is divided 
Family Formicidae

Analysis between the hindwings Tipologies and phylogenetic hypothesis according to Brady et al. (2006),

Morreau et al. (2006) and Morreau and Bell (2013)

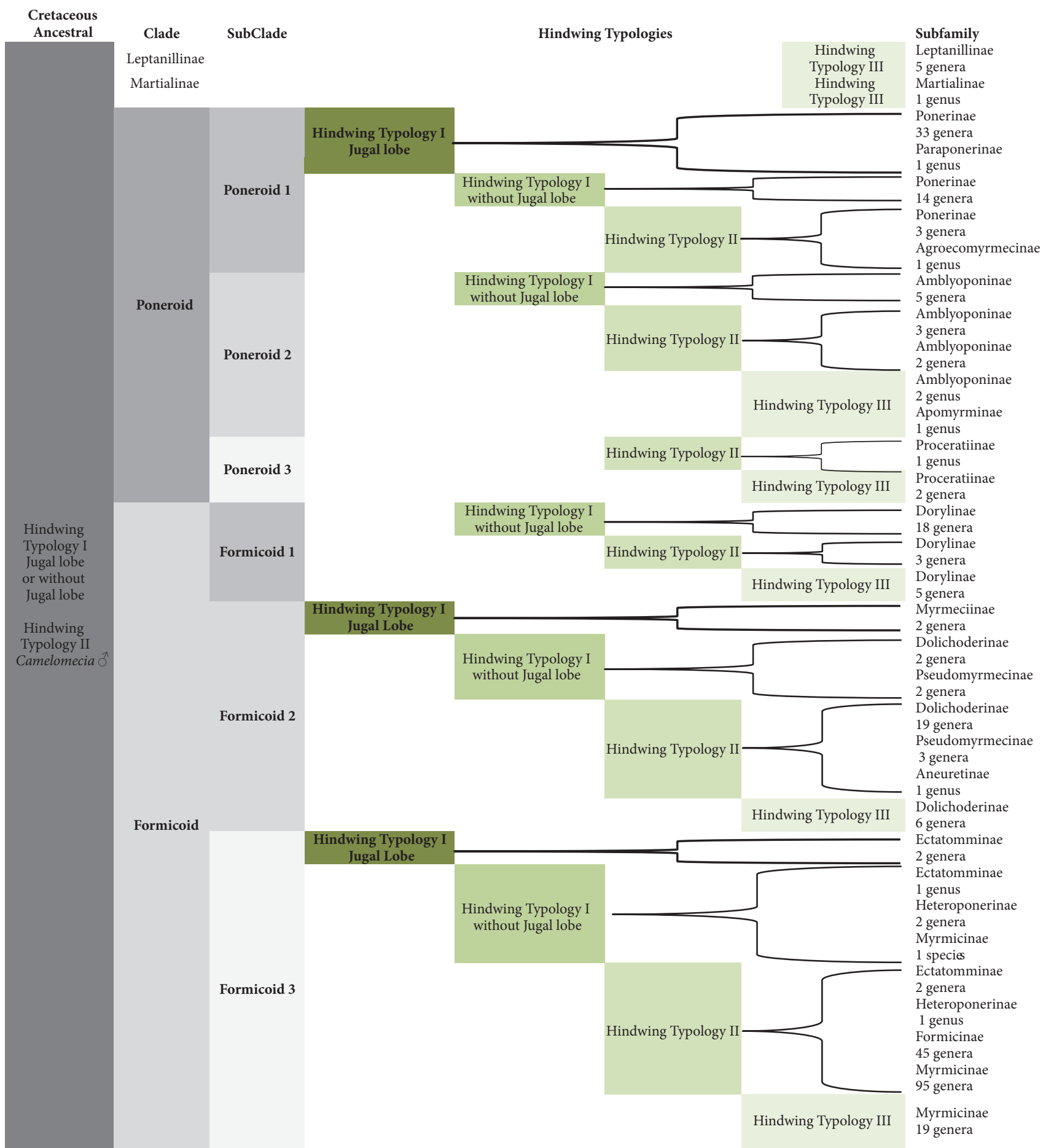

Figure 6: Analysis of the hindwings Typologies, in each Clade and Subclade, with the corresponding numbers of genera in each Subfamily. 


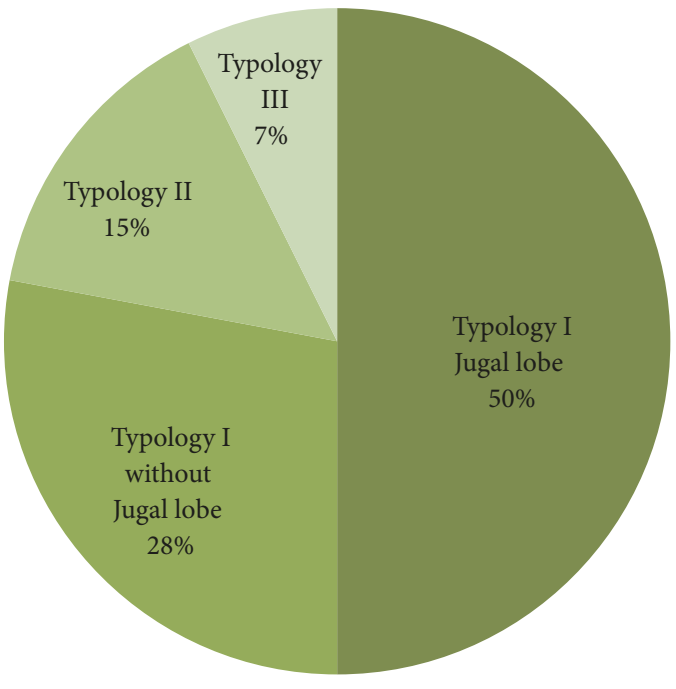

Clade Poneroid: Hindwings Typologies

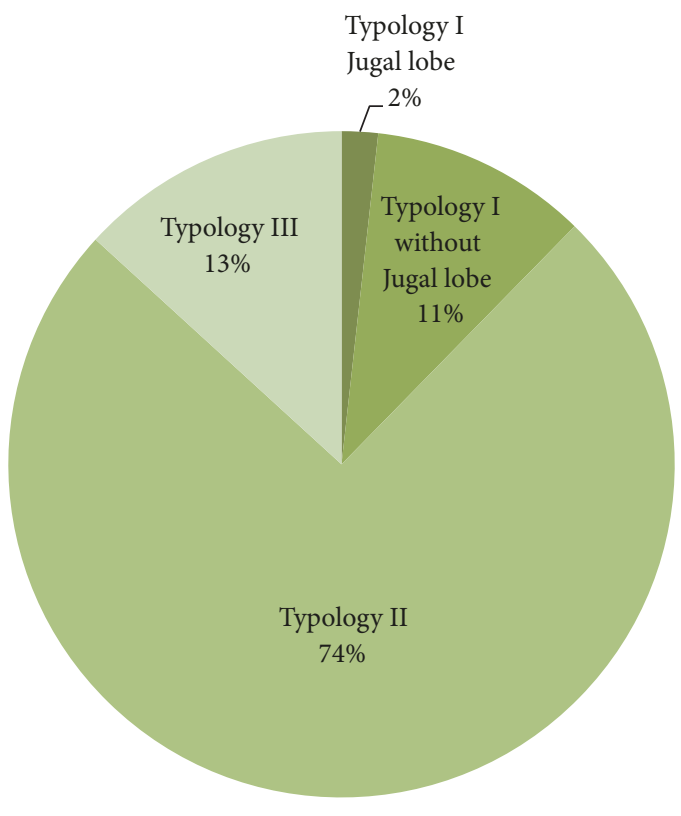

Clade Formicoid: Hindwings Typologies

Figure 7: Percentages related to the genera for each Typology, respectively, in the Clade Poneroid and Formicoid.

into three phylogenetically separate groups: the first group comprises the genera of the Subfamily Dorylinae that in this analysis we called Subclade Formicoid 1; the second group includes the genera of the Subfamilies Myrmeciinae, Pseudomyrmecinae, Dolichoderinae, and Apomyrminae, which we called Subclade Formicoid 2; and the third group includes the genera of Subfamilies Ectatomminae, Heteroponerinae, Myrmicinae, and Formicinae, which we called Subclade Formicoid 3. So in this analysis also the Clade Formicoid is divided into three phylogenetically distinct Subclades.

Figure 6 shows the number of genera in each Clade and Subclade with the corresponding hindwing Typologies. Figure 7 shows the percentages related to the genera, for each Typology, in the two Clades. Figure 8 represents, with graphs, the percentages related to genera for each Typology in the six Subclades.

\section{Discussion}

The hindwings of the species encountered in the Cretaceous (100-75 Ma) present Typology I with or without jugal lobe. From these few data, it can be said that the hindwings of Typology I represent the most ancestral morphology [6, 11]. The jugal lobe represents a pleiomorphic character in the Order Hymenoptera. Unfortunately, in the hindwings of the Cretaceous, the proximal part of the anal area is not described because it is not visible or deteriorated; therefore the presence/absence of the jugal lobe remains unknown. The jugal lobe is present only in the hindwings of Typology I and is found in some extant genera belonging to the Subfamilies Ponerinae, Paraponerinae, Myrmeciinae, and Ectatomminae $[3,4,22]$. In both the Subfamilies Formicinae and Myrmicinae, individuals were found in fossil deposits dating back to the Cretaceous, respectively, the genus Kyromyrma [23] and Afromyrma [24] but, unfortunately, the wings are not known. Other specimens encountered in Cretaceous deposits have been included in the current Subfamilies, but hindwings are still unknown: Cananeuretus occidentalis (Subfamily Aneuretinae; [25]); Chronomyrmex medicinehatensis and Eotapinoma macalpini (Subfamily Dolichoderine [26, 27]); Canapone dentata (Subfamily Ectatomminae [26]); Afropone oculata, A. orapa (Subfamily Ponerinae [24]).

In the two Clades, Poneroid and Formicoid, there is a clear difference in the results, with a much higher percentage of hindwings with Typology I in the Clade Poneroid (78\%) compared to the Clade Formicoid (13\%) (Figure 7). By analyzing the hindwings in each Subclade, it is noted that Typology I shows very high occurrences in the Subclades Poneroid 1 (92\%), Formicoid 1 (69\%), and Poneroid 2 (39\%) and minor in the Subclades Formicoid $2(18 \%)$ and Formicoid 3 (4\%) (Figure 8). In addition, the hindwings of Typology I with jugal lobe are only present in the Subclades Poneroid $1(65 \%)$, Formicoid $2(5 \%)$, and Formicoid $3(1 \%)$. In the Subclade Formicoid 3, the entire Subfamily Formicinae presents only hindwings of Typology II and the Subfamily Myrmicinae only hindwings of Typology II and Typology III (with the unique exception known in the species Solenopsis bicolor with hindwing "azteca type"). The hypothesis that a reduction in the structure of the hindwing veins occurred in the course of evolution assumes that from hindwings of Typology I, with/without jugal lobe, are subsequently evolving the other Typologies. This could be confirmed by the presence of genera with hindwings of Typology I in all most representative Subclade (see Figure 6). The genera, for each Subclade, which have hindwings of Typology I are listed in Table 1 with relative notes. Only in the Subclades Poneroid 3 


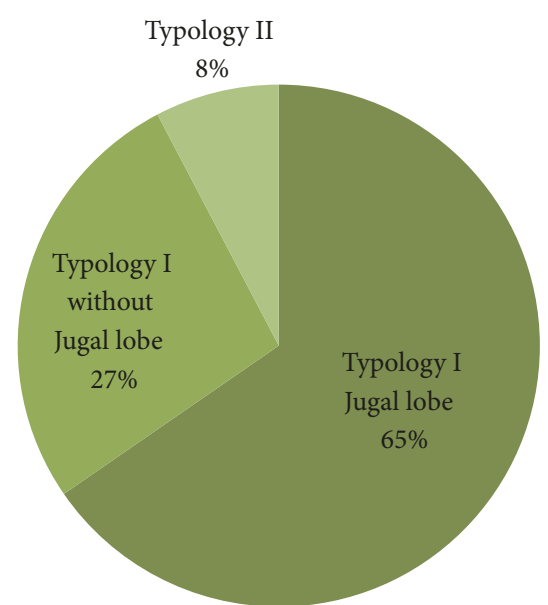

Poneroid 1

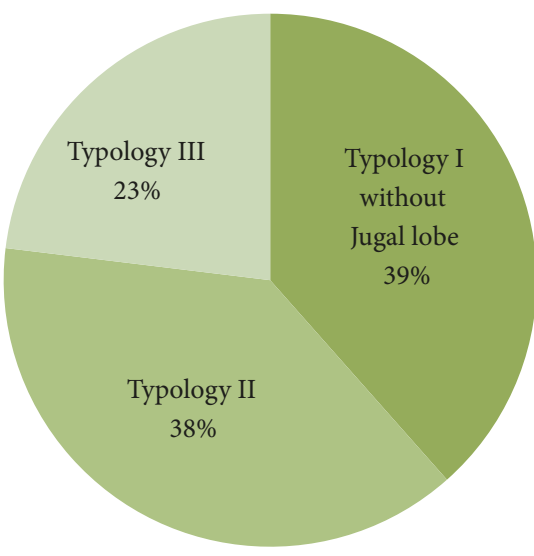

Poneroid 2

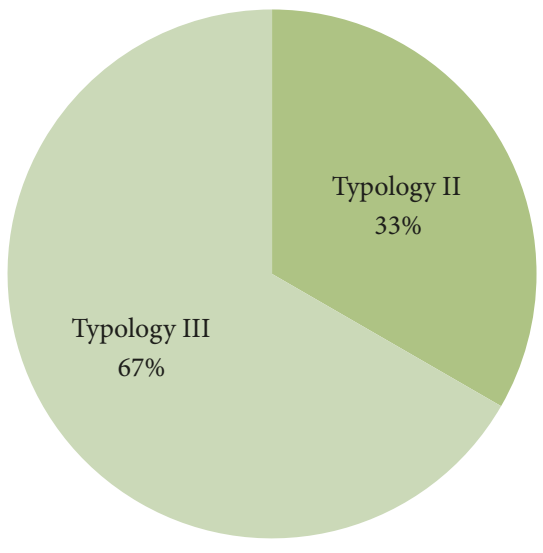

Poneroid 3

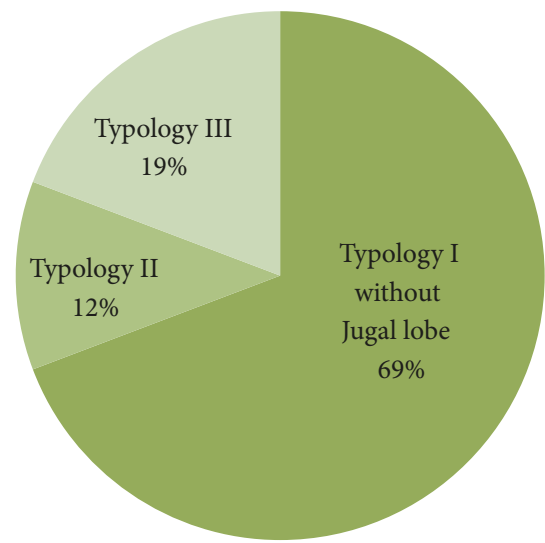

Formicoid 1

Typology I

Jugal lobe

$5 \%$

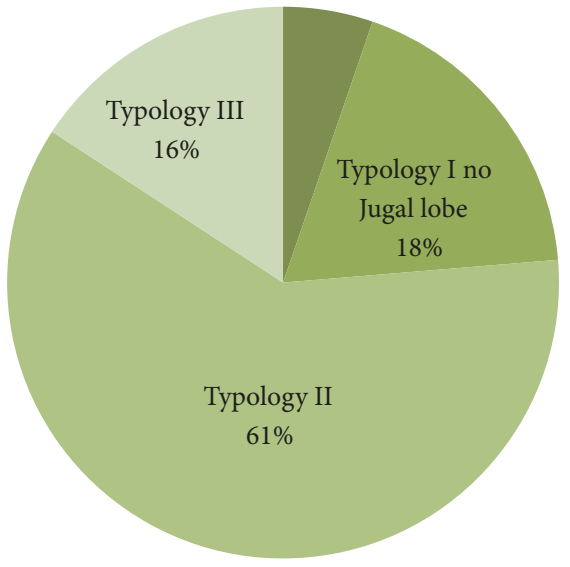

Formicoid 2

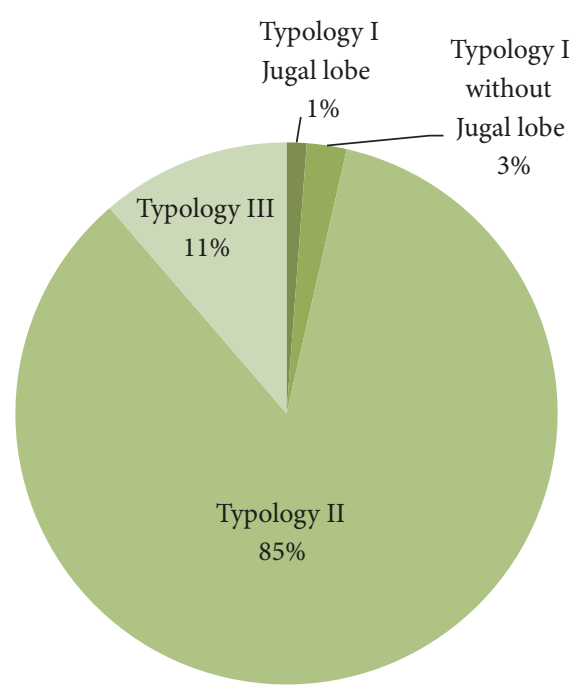

Formicoid 3

Figure 8: Percentages related to genera, for each hindwings Typology, in six Subclades of the Family Formicidae. 
TABLE 1: Genera with hindwing of Typology I divided for Subclades.

\begin{tabular}{|c|c|c|c|c|}
\hline \multicolumn{5}{|c|}{ Hindwing of Typology I } \\
\hline Subclades & Subfamilies & \multicolumn{2}{|c|}{ Genera with Jugal lobe } & Genera without Jugal lobe \\
\hline \multirow{19}{*}{ Poneroid 1} & \multirow{18}{*}{ Ponerinae $^{1}$} & Anochetus & Mesoponera & Asphinctopone \\
\hline & & Asphinctopone & Myopsias & Austroponera \\
\hline & & Austroponera & Neoponera & Belonopelta \\
\hline & & Belonopelta & Odonthomachus & Buniapone \\
\hline & & Bothroponera & Odontoponera & Cryptopone \\
\hline & & Brachyponera & Ophthalmopone & Emeryopone \\
\hline & & Buniapone & Pachycondyla & Euponera \\
\hline & & Centromyrmex & Paltothyreus & Hypoponera \\
\hline & & Diacamma & Phrynoponera & Leptogenys \\
\hline & & Dinoponera & Platythyrea & Loboponera \\
\hline & & Ectomomyrmex & Plectrocena & Mayaponera \\
\hline & & Emeryopone Euponera & Plectroctena & Myopsias \\
\hline & & Hagensia & Promyopsias & Parvaponera \\
\hline & & Harpegnathos & Psalidomyrmex & Ponera \\
\hline & & Loboponera & Pseudoneoponera & Promyopias \\
\hline & & Mayaponera & Rasopone & Pseudoponera \\
\hline & & Megaponera & Streblognathus & \\
\hline & & Mesoponera & & \\
\hline & Paraponerinae & \multicolumn{2}{|c|}{ Paraponera } & - \\
\hline \multirow{5}{*}{ Poneroid 2} & \multirow{5}{*}{ Amblyoponinae $^{2}$} & \multirow{5}{*}{\multicolumn{2}{|c|}{-}} & Amblyopone \\
\hline & & & & Fulakora \\
\hline & & & & Myopopone \\
\hline & & & & Mystrium \\
\hline & & & & Stigmatomma \\
\hline \multirow{18}{*}{ Formicoid 1} & \multirow{18}{*}{ Dorylinae } & \multirow{18}{*}{\multicolumn{2}{|c|}{ - }} & Acanthostichus \\
\hline & & & & Aenictogiton \\
\hline & & & & Aenictus \\
\hline & & & & Cerapachys \\
\hline & & & & Cheliomyrmex \\
\hline & & & & Chrysapace \\
\hline & & & & Cylindromyrmex \\
\hline & & & & Dorylus \\
\hline & & & & Eciton \\
\hline & & & & Eusphinctus \\
\hline & & & & Labidus \\
\hline & & & & Lioponera \\
\hline & & & & Neivamyrmex \\
\hline & & & & Neocerapachys \\
\hline & & & & Nomamyrmex \\
\hline & & & & Parasyscia \\
\hline & & & & Simopone \\
\hline & & & & Yunodorylus \\
\hline \multirow{6}{*}{ Formicoid 2} & \multirow{2}{*}{ Myrmeciinae } & My & & \multirow{2}{*}{-} \\
\hline & & \multicolumn{2}{|c|}{ Nothomyrmecia } & \\
\hline & Pseudomyrmecinae & \multirow{2}{*}{\multicolumn{2}{|c|}{ - }} & Pseudomyrmex gracilis \\
\hline & & & & Tetraponera \\
\hline & Dolichoderinae $^{4}$ & \multirow{2}{*}{\multicolumn{2}{|c|}{ - }} & Anonychomyrma \\
\hline & & & & Azteca \\
\hline
\end{tabular}


TABle 1: Continued.

\begin{tabular}{lccc}
\hline & & Hindwing of Typology I & \\
Subclades & Subfamilies & Genera with Jugal lobe & Genera without Jugal lobe \\
\hline & Ectatomminae & Ectatomma & Gnamptogenys \\
Formicoid 3 & Rhytidoponera & Acanthoponera \\
& Heteroponerinae & Heteroponera & Solenopsis bicolor \\
\hline
\end{tabular}

Notes Table 1.

1: Ponerinae: the genera Austroponera, Belonopelta, Emeryopone, Aspinctopone, Loboponera, and Mayaponera. I do not know the presence/absence of the Jugal lobe; the genus Euponera: I have encountered in some species the presence and in others the absence of Jugal lobe; the genera Hypoponera and Ponera described hindwings of Typology I and Typology II.

2: Amblyoponinae: the genus Fulakora described hindwings of Typologies I, II, and III.

3: Pseudomyrmecinae: the genera Tetraponera and Pseudomyrmex described hindwings of Typologies I and II.

4: Dolichoderinae: the genus Anonychomyrma described hindwings of Typology I without Jugal lobe and Typology II; the genus Azteca described hindwings of Typology I without Jugal lobe "azteca type" (Figure 1).

5: Ectatomminae: the genus Gnamptogenys described hindwings of Typology I without Jugal lobe and Typology II (Figure 2).

6: Heteroponerinae: the genus Heteroponera described hindwings of Typology I without Jugal lobe and Typology II.

(Subfamily Proceratiinae), which is represented by just three genera, hindwings of Typology I are not known.

\section{Conclusion}

This study represents the first hindwings revision of the Family Formicidae, showing an overview of the different distribution of Typologies. In the future, a more in-depth study at the level of Subfamily and Tribe would give a more comprehensive view. In fact, within each Typology we can identify various differences in the morphology of the veins, such as the presence/absence of the anal 2 vein or radial 1 vein [4]. Thus, these data could be useful with comparative analyzes between morphological, behavioral, and molecular genetic characteristics, in order to improve and develop new phylogenetic hypotheses for the Subfamily, Tribe or Groupgenera level.

\section{Data Availability}

The data supporting this taxonomic review are from previously reported studies and datasets, which have been cited and available from the corresponding author upon request.

\section{Conflicts of Interest}

The authors declare that they have no conflicts of interest.

\section{Acknowledgments}

This research received support from the development agency Capes and $\mathrm{CNPq}$ (Brazil).

\section{References}

[1] B. Hölldobler and E. O. Wilson, The Ants, The Belknap Press of Harvard University Press, Cambridge, UK, 1990.

[2] W. M. Wheeler, Ants - Their Structure, Development and Behavior, Columbia University Biological Series IX, 1910.
[3] S. Cantone, "Winged Ants - The Male. Dichotomous key to genera of winged ơ $0^{*}$ ants in the World," in Behavioral Ecology of Mating Flight, S. Cantone, Ed., pp. 1-318, Catania, Italy, 2017, http://www.wingedant.com/.

[4] S. Cantone, "Winged ants -the queen, Dichotomous key to genera of winged 우 ants in the world," in The Wings of Ants: Morphological and Systematic Relationships, S. Cantone, Ed., pp. 1-244, Catania, Italy, 2018, http://www.wingedant.com/.

[5] K. S. Perfilieva, "Trends in evolution of ant wing venation (hymenoptera, formicidae)," Entomological Review, vol. 90, no. 7, pp. 857-870, 2010.

[6] W. L. Brown and W. L. Nutting, "Wings venation and the phylogeny of the Formicidae (Hymenoptera)," American Entomology Society, vol. 75, no. 3-4, pp. 113-132, 1949.

[7] C. Emery, "La nervulation de laile anterieure des Formicides," Revue suisse de Zoologie, vol. 21, no. 15, 1913.

[8] K. S. Perfilieva, "Wing venation anomalies in sexual individuals of ants (Hymenoptera, Formicidae) with different strategies of mating behavior," Entomological Review, vol. 80, no. 9, pp. 1181$1188,2000$.

[9] B. Delage-Darchen, "Évolution de l'aile chez les fourmis Crematogaster (Myrmicinae) d'Afrique," Insectes Sociaux, vol. 20, no. 3, pp. 221-242, 1973.

[10] K. Ogata, "A generic synopsis of the poneroid complex of the family formicidae in japan (hymenoptera), part ii, subfamily myrmicinae," Bulletin of the Institute of Tropical Agriculture, vol. 14, pp. 61-149, 1991.

[11] N. Kusnezov, "El ala posterior de las hormigas," Acta Zoologica Lilloana, vol. 18, pp. 367-378, 1962.

[12] M. Yoshimura and B. L. Fisher, "A revision of male ants of the malagasy region (hymenoptera: formicidae): key to genera of the subfamily dolichoderinae," Zootaxa, vol. 2794, pp. 1-34, 2011.

[13] F. Serna, B. Bolton, and W. MacKay, "On the morphology of procryptocerus (hymenoptera: formicidae), some comments and corrigenda," Zootaxa, vol. 2923, pp. 67-68, 2011.

[14] S. G. Brady, T. R. Schultz, B. L. Fisher, and P. S. Ward, "Evaluating alternative hypotheses for the early evolution and diversification of ants," Proceedings of the National Acadamy of Sciences of the United States of America, vol. 103, no. 48, pp. 18172-18177, 2006. 
[15] C. S. Moreau, C. D. Bell, R. Vila, S. B. Archibald, and N. E. Pierce, "Phylogeny of the ants: Diversification in the age of angiosperms," Science, vol. 312, no. 5770, pp. 101-104, 2006.

[16] C. S. Moreau and C. D. Bell, "Testing the museum versus cradle tropical biological diversity hypothesis: phylogeny, diversification, and ancestral biogeographic range evolution of the ants," Evolution, vol. 67, no. 8, pp. 2240-2257, 2013.

[17] AntWeb, "Photos CASENT0904619 Solenopsis bicolor Emery; owned by Museo di Scienze Naturali di Genova, Italy," Syntype Carebarella bicolor punctatorugosa, http://www.antweb.org/, 2018.

[18] K. S. Perfilieva, "Wing venation in army ants (hymenoptera, formicidae) and its importance for phylogeny," Zoologicheskii Zhurnal, vol. 81, no. 10, pp. 1239-1250, 2002.

[19] P. Barden and D. A. Grimaldi, "Adaptive radiation in socially advanced stem-group ants from the cretaceous," Current Biology, vol. 26, no. 4, pp. 515-521, 2016.

[20] S. Bruce Archibald, K. R. Johnson, R. W. Mathewes, and D. R. Greenwood, "Intercontinental dispersal of giant thermophilic ants across the Arctic during early Eocene hyperthermals," Proceedings of the Royal Society B Biological Science, vol. 278, no. 1725, pp. 3679-3686, 2011.

[21] H. Lutz, "Eine neue Unterfamilie der Formicidae ( Insecta: Hymenoptera) aus dem mittel-eozanen Olschiefer der "Grube Messel” bei Darmstadt (Deutschland, S-Hessen)," Senckenbergiana Lethaea, vol. 67, no. 1/4, pp. 177-218, 1986.

[22] B. E. Boudinot, "Contributions to the knowledge of formicidae (Hymenoptera, Aculeata): A new diagnosis of the family, the first global male-based key to subfamilies, and a treatment of early branching lineages," European Journal of Taxonomy, vol. 2015, no. 120, pp. 1-62, 2015.

[23] D. Grimaldi and D. Agosti, "A formicine in New Jersey Cretaceous amber (Hymenoptera: Formicidae) and early evolution of the ants," Proceedings of the National Acadamy of Sciences of the United States of America, vol. 97, no. 25, pp. 13678-13683, 2000.

[24] G. M. Dlussky, D. J. Brothers, and A. P. Rasnitsyn, “The first late cretaceous ants (hymenoptera: formicidae) from Southern Africa, with comments on the origin of the Myrmicinae," Insect Systematics and Evolution, vol. 35, no. 1, pp. 1-13, 2004.

[25] M. S. Engel and D. A. Grimaldi, "Primitive new ants in cretaceous amber from Myanmar, New Jersey, and Canada (hymenoptera: formicidae)," American Museum Novitates, no. 3485, pp. 1-23, 2005.

[26] G. M. Dlussky, "New ants (hymenoptera, formicidae) from canadian amber," Paleontological Journal, vol. 33, no. 4, pp. 409412, 1999.

[27] R. C. McKellar, J. R. N. Glasier, and M. S. Engel, "New ants (Hymenoptera: Formicidae: Dolichoderinae) from Canadian Late Cretaceous amber," Bulletin of Geosciences, vol. 88, no. 3, pp. 583-594, 2013. 


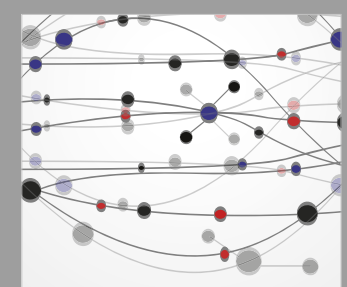

The Scientific World Journal
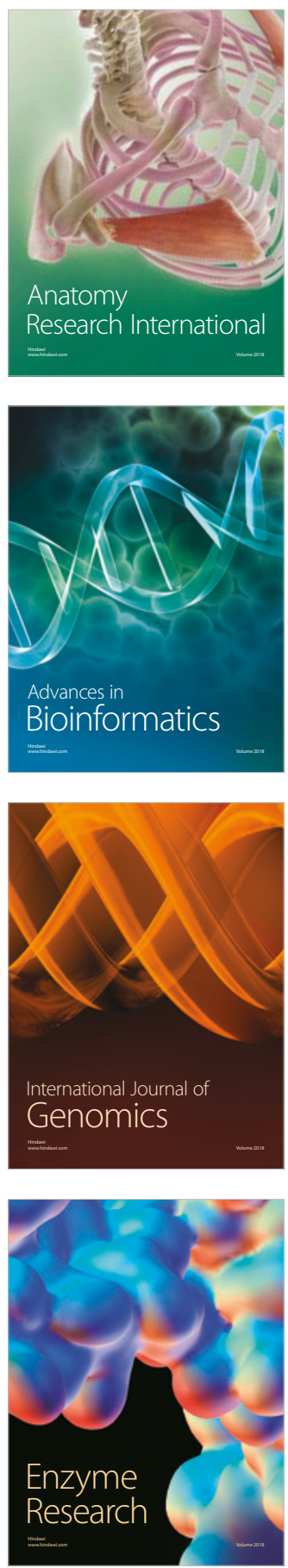
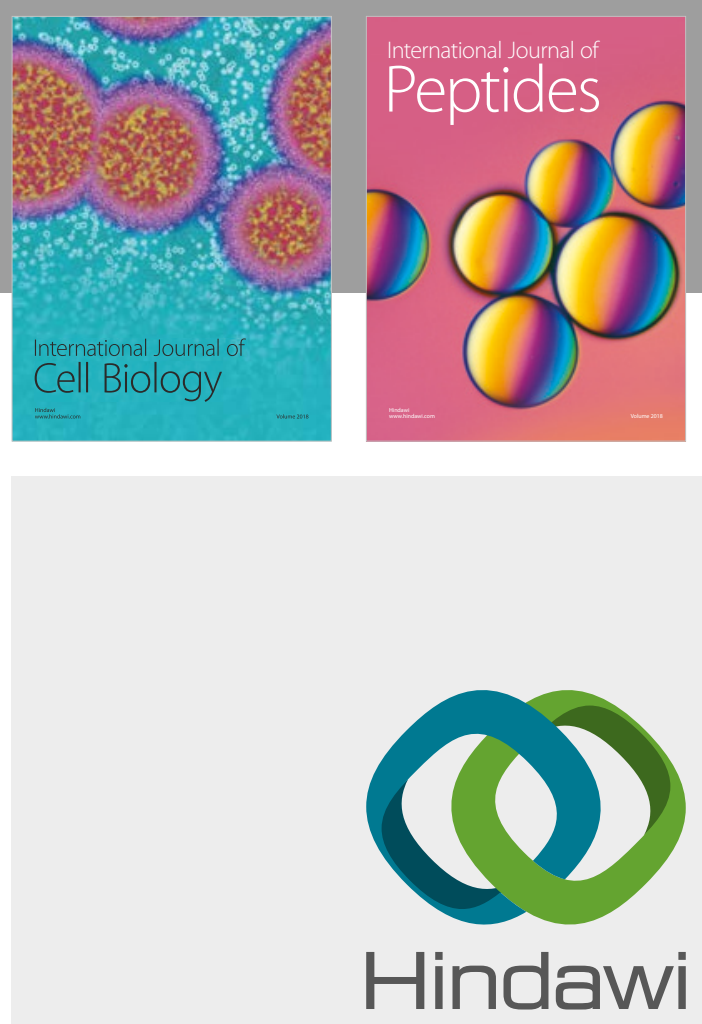

Submit your manuscripts at

www.hindawi.com
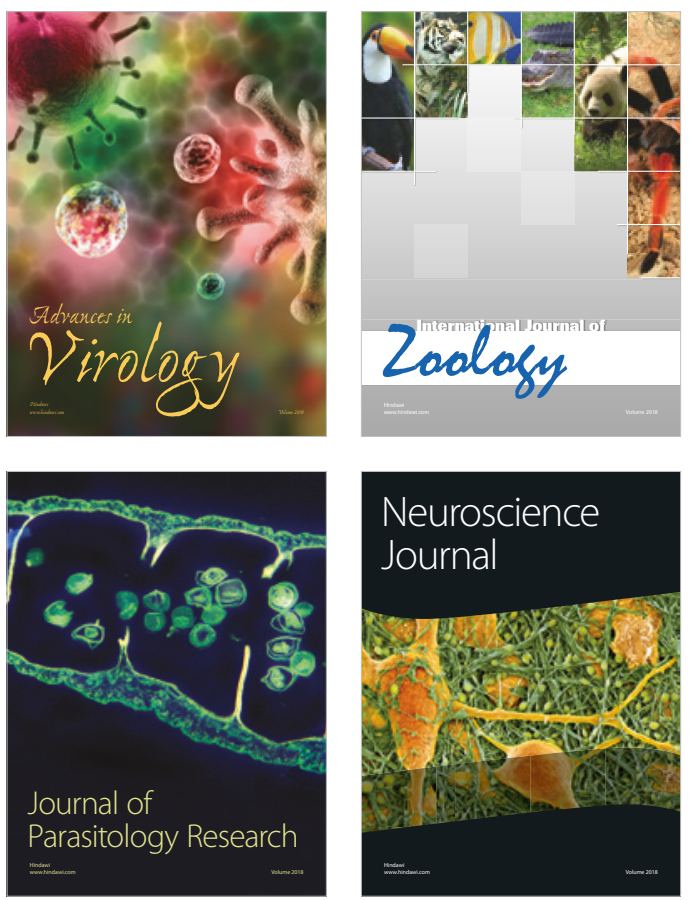
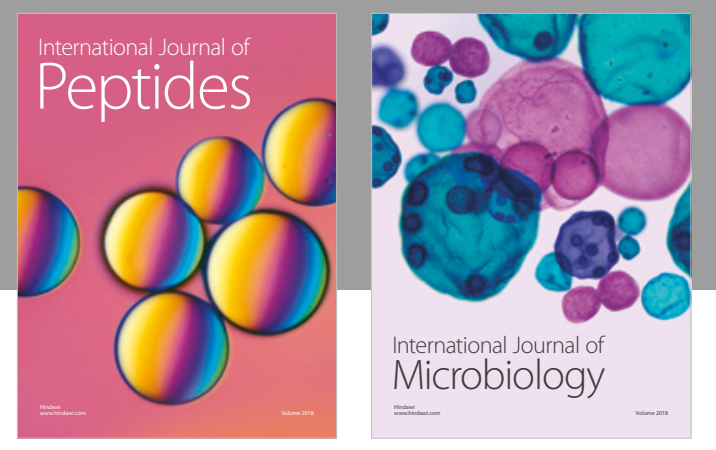

nternational Journal of Microbiology
Journal of
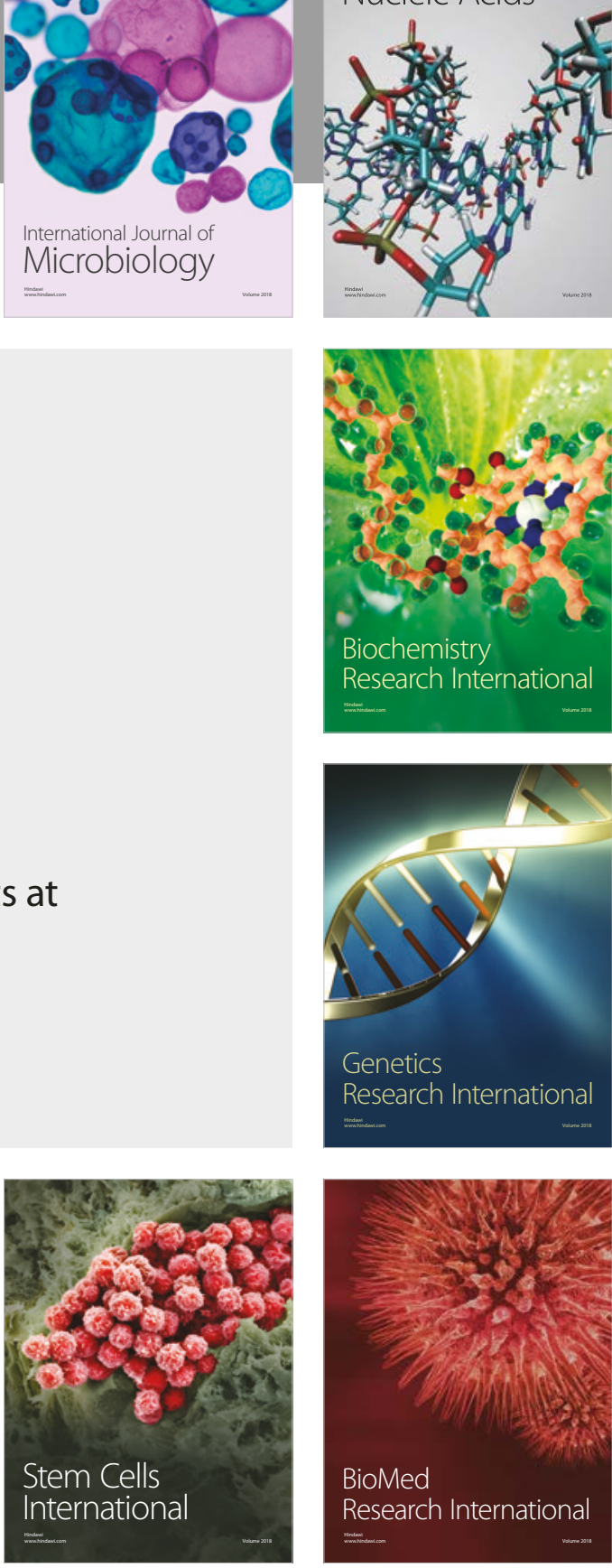
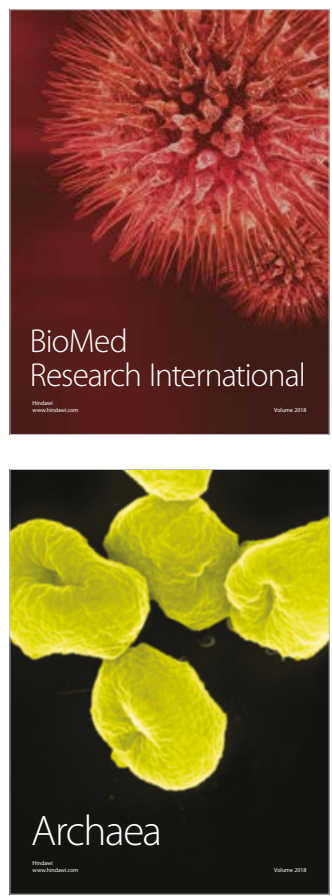